\section{A Passion for Wildlife: The History of the Canadian Wildlife Service}

By J. A. Burnett. UBC Press, Vancouver, British Columbia. Hardcover. 331 pages, \$27.95 paper, \$85.00 cloth.

Anyone who is prejudiced against "civil servants" should read this book. The Canadian Wildlife Service, from its inception, has contained a cadre of dedicated scientists who work long hours, share their knowledge

\section{NEW TitLes}

\section{Zoology}

$\dagger$ The American Bison. By D. Lott. 2004. University of California Press. 229 pages, \$40 U.S. Paper.

$\dagger$ Annotated Bibliography of the Quaternary Vertebrates of Northern North America. 2003. Edited by C. R. Harrington. University of Toronto Press. xxii plus 539 pages, not illustrated. \$150 Cloth, \$75. Paper.

Annotated Checklist of the Birds of Chile. By Manuel Marín. Lynx Edicions, Barcelona, Spain. US\$15.75.

Behavior and Ecology of Pacific Salmon and Trout. By T. Quinn. UBC Press, 2029 West Mall, Vancouver, British Columbia V6T 1 Z2 Canada. 400 pages, $\$ 85$.

Big Cat Diary: Leopard. By Jonathan Scott and Angela Scott. Harper Collins. 128 pages, \$42.

* The Bird Almanac. By D. Bird. 2004. Key Porter Books, 70 The Esplanade, Toronto, Ontario, Canada. xvii +460 pages, not illustrated, \$24.95. Paper.

Birding in Venezuela. By Mary Lou Goodwin. Lynx Edicions, Barcelona, Spain. US\$ 5.60.

Birds of South Asia: The Ripley Guide. Volumes I and II. By Pamela C. Rasmussen and John C. Anderton. Lynx Edicions, Barcelona, Spain. US\$95.

Bowerbirds - Ptilonorhychidae. Edited by Clifford Frith. Oxford University Press, 70 Wynford Drive, Don Mills, Ontario M3C 1J9 Canada. 416 pages. \$209 Cloth.

$\dagger$ British Columbia - A Natural History. By R. and S. Cannings. 2004. Greystone Books, Douglas and McIntyre, Vancouver, British Columbia, Canada. ix + 341 pages. \$39.95 Paper.

$\dagger$ The Buffalo Wolf. 2003. By Lu Carbyn. Smithsonian books, Washington, D.C., USA. 248 pages. Paper.

Curassows and Related Birds. By Jean Delacour and Dean Amadon. Update Chapter by Josep del Hoyo and Anna Motis. Illustrated by Albert Earl Gilbert. Lynx Edicions, Barcelona, Spain. US\$75.

$\dagger$ Ecology and Conservation of Birds in the Salton Sink: an Endangered Ecosystem. By W. David Shuford and Kathy C. Molina. 2004. Studies in Avian Biology Number 27. Cooper Ornithological Society. widely, and on occasion risk their lives for the sake of the environment. Burnett, an insider, tells the story of this valuable and generally cost-effective organization, beginning in 1916 with the five men who were involved in drafting and implementing, from the Canadian side, the Migratory Birds Convention Act. In 1918, Hoyes Lloyd was appointed as Supervisor of Wild Life Protection in Canada. Lloyd, in turn, appointed three Federal Migratory Bird Officers. The

* A Field Guide to the Bird's Nests and Eggs of Alaska Coastal Tundra. By T. Bowman. 2004. Alaska Sea Grant College Program.

$\dagger$ A Guide to Hawk Watching in NA. By D. Heintzleman. 2004. The Globe Pequot Press.

† Mammal Tracks and Signs. By Mark Elbroch. 2004. Stackpole Books.

$\dagger$ Key Marine Habitat Sites for Migratory Birds in Nunavut and the Northwest Territories. 2004. By M. Mallory and A. Fontaine. 2004. Canadian Wildlife Service, Ottawa, Ontario K1A 0H3. Paper.

† Orca - Visions of the Killer Whale. By P. Knudtson. 2004. Greystone Books, Vancouver, British Columbia. xvii +110 pages. $\$ 19.95$. Paper.

Readers Digest Birds of Canada. Edited by R. Greenberg et al. 2004. Dorling Kindersly India Ltd., c/o Tourmaline Editions, 662 King Street West, Suite 304, Toronto, Ontario M5V $1 \mathrm{M} 7$.

Reptiles and Amphibians of the Amazon: An Ecotourist's Guide. By R. D. Bartlett and P. Bartlett Florida University Presses, USA. 291 pages. \$57 Canadian. Paper.

Wild Down Under: The Natural History of Australasia. By Neil Nightingale, Jeni Clevers, Neil Pearson and Mary Summerill. BBC Video. 240 pages, \$50 Canadian. Cloth.

\section{Botany}

The Wild Flowers of Britain and Ireland - The Complete Guide to the British and Irish Flora. By Marjorie Blamey, Richard Fitter and Alastair Fitter. A \& C Black. 512 pages, $\$ 42$ Canadian. Paper.

\section{Environment}

*Bull's Eye - Unraveling the medical mystery of Lyme Disease. By Jonathon Edlow. 2004. Yale University Press, Box 209040, New Haven, Connecticut.

$\dagger$ Canoeing, Kayaking \& Hiking Temagami. By Hap Wilson. 2004. The Boston Mills Press (Firefly Books), 132 Main Street, Erin, Ontario. 112 pages, \$24.95.

$\dagger$ Chicken Soup for the Fisherman's Soul. By J. Canfield, M. Hansen, K. \& Dahlynn McKowen. 2004. Health Communications Inc. Paper. 
Dictionary of Ecology. By Michael Allaby. 2004. Oxford University Press, 70 Wynford Drive, Don Mills, Ontario M3C 1J9. 448 pages, $\$ 29.95$.

† The Importance of Species. Edited by P. Karliva and S. Levin. 2004. Princeton University Press, 41 William Street, Princeton, New Jersey. xvi +427 pages, not illustrated, Paper.

† Lewis and Clarke on the Great Plains. By Paul Johnsgard. 2003. University of Nebraska Press. xiv +143 pages, $\$ 14.95$ U.S.

† Missinaibi. By Hap Wilson. 2004. The Boston Mills Press (Firefly Books), 132 Main Street, Erin, Ontario. 134 pages, $\$ 24.95$.

$\dagger$ A place between the tides: A naturalist's reflections on the salt marsh. By Harry Thurston. 2004. Greystone Books. Paper. \$22.95 CAAD, \$15.00 U.S.

$\dagger$ Politics of the Wild - Canada \& Endangered Species. Edited by K. Beazley and R. Boardman. 2004. Oxford University Press, 70 Wynford Drive, Don Mills, Ontario. x + 254 pages, not illustrated, \$29.95 Paper.

Population Ecology: First Principles. By John H. Vandermeer and Deborah E. Goldberg. Princeton UP, USA. 280 pages, \$123 Cdn, Cloth.

A Primer of Ecological Genetics. By J. Conner and D. Hartt. 2004. Sinauer Associates, Box 407, Sunderland, Massachusetts. 207 pages, \$34.95 U.S., Paper.
* Resource and Environmental Management in Canada. Edited by B. Mitchell. 2004. Oxford University Press, 70 Wynford Drive, Don Mills, Ontario. x + 600 pages, $\$ 29.95$ Paper.

$\dagger$ Rivers of the Upper Ottawa Valley. By Hap Wilson. 2004. The Boston Mills Press (Firefly Books), 132 Main Street, Erin, Ontario. 112 pages, \$24.95.

† The Selbourne Pioneer. By T. Dodswell. 2004. Ashgate Publising Company, Suite 420, 101 Cherry St., Burlington, Vermont, USA. xvii + 238 pages, not illustrated. Paper.

† Shaped by the West Wind - Nature and History in Georgian Bay. By C. Campbell. 2004. UBC Press, 2029 West Mall, Vancouver, British Columbia, V6T 1 Z2 Canada. 256 pages, $\$ 85 \mathrm{Cdn}$.

The Smithsonian Atlas of the Amazon. By Michael Goulding, Ronaldo Barthem and Efrem Ferreira. Smithsonian Books, Washington, D.C., USA. 255 pages, $\$ 75 \mathrm{Cdn}$. Cloth.

$\dagger$ Teaching in Eden. 2003. By J. Janovy Jr. Routledge, 29 West 35th St., New York, New York 10001 USA. 187 pages, not illustrated, \$22.95 U.S., Paper.

$\dagger$ Wilderness Rivers of Manitoba. By Hap Wilson and S. Aykroyd. 2004. The Boston Mills Press (Firefly Books), 132 Main Street, Erin, Ontario, Canada. 112 pages, \$24.95.

† Available
*Assigned 